\title{
PERTANGGUNGJAWABAN PIDANA TERHADAP KORPORASI BERDASARKAN UU NO 20 TAHUN 2001 TENTANG PEMBERANTASAN TINDAK PIDANA KORUPSI
}

\author{
Sabungan Sibarani, Faisal Santiago \\ Dosen Pascasarjana, Fakultas Hukum Universitas Borobudur \\ Guru Besar Pascasarjana, Universitas Borobudur \\ ssibarani01@gmail.com
}

\begin{abstract}
Abstrak
Pertanggungjawaban pidana korporasi atas tindak pidana korupsi yang dilakukan oleh korporasi dapat dilakukan oleh: korporasi, pengurus atau pengurus dan korporasi. Tindak pidana korupsi yang dapat dilakukan oleh korporasi adalah tindak pidana korupsi yang diatur dalam Pasal 2 ayat (1), Pasal 3, Pasal 5 ayat (1), Pasal 6 ayat (1), Pasal 7, Pasal 13, Pasal 15, dan Pasal 16 Undang-Undang 20 Tahun 2001 tentang Pemberantasan Tindak Pidana Korupsi. Jadi tidak semua tindak pidana korupsi dapat dilakukan oleh korporasi.Dengan lahirnya Perma 13/2016 korporasi bisa dimintai pertanggungjawaban terkait tindak pidana korupsi yang dilakukan oleh pengurus atau organ korporasi. Dengan demikian, pengurus merupakan direksi maupun komisaris yang telah tercantum dalam anggaran dasar sebuah korporasi. Untuk melihat direksi maupun komisaris tersebut dapat dimintai pertanggungjawaban pidana dalam hal tindak pidana korporasi, maka perlu melihat sejauh mana keterlibatan direksi atau komisaris dalam tindak pidana yang dilakukan oleh korporasi, dimana hal ini tercermin dalam adanya niat jahat (mens rea) dan perbuatan jahat (actus reus) yang dilakukan oleh direksi atau komisaris tersebut.
\end{abstract}

\section{Kata Kunci: Pertanggungjawaban Pidana, Korporasi, Korupsi.}

\section{PENDAHULUAN}

\section{A. Latar Belakang Masalah}

Perkembangan hukum dewasa ini semakin dikuti oleh desakan era globalisasi, seolah-olah memaksa hukum terus menyempurnakan dirinya, hukum adalah tatanan yang utuh (holistik) selalu bergerak, baik secara evolutif maupun revolusioner. ${ }^{1}$ Sifat pergerakan itu merupakan sesuatu yang tidak dapat dihilangkan atau ditiadakan, tetapi sebagai sesuatu yang eksis dan prinsipil. ${ }^{2}$ maka darinya hukum itu progresif, sifat hukum yang progresif disatu sisi juga diikuti oleh perekonomian tiap bangsa yang semakin berkembang,

\footnotetext{
${ }^{1}$ Otje Salman dan Anthon F Susanto, Teori Hukum (Mengingat, Mengumpulkan dan Membuka Kembali), Bandung, Refika Aditama, 2013, hlm. 139. hlm 140
}

sehingga kejahatan juga berkembang mengikuti globalisasi ekonomi, kejahatan ekonomi antara satu negara dengan negara lainnya semakin saling berkembang, sehingga ketentuan hukum di bidang perdagangan internasional dan bisnis transnasional semakin diperlukan juga.

Dahulu ada semacam adagium yang menyatakan semakin miskin suatu bangsa semakin tinggi tingkat kejahatannya, sekarang adagium tersebut hanya berlaku bagi kejahatan konvensional, seperti perampokan, pencurian, penipuan, penggelapan dan lain-lain. Soedjono Dirdjosisworo menyatakan bahwa :

"Kejahatan sekarang menunjukan bahwa kemajuan ekonomi juga menimbulkan kejahatan bentuk baru yang tidak kurang bahaya dan besarnya korban yang diakibatkannya. Indonesia dewasa ini sudah dilanda 
kriminalitas kontemporer yang cukup mengancam lingkungan hidup, sumber energi dan pola-pola kejahatan di bidang ekonomi seperti kejahatan bank, kejahatan computer, penipuan terhadap konsumen berupa barang-barang produksi kualitas rendah yang dikemas indah dan dijajakan lewat advertensi secara besar-besaran dan berbagai pola kejahatan korporasi yang beroperasi lewat penetrasi dan penyamaran. ${ }^{3}$

Kongres PBB V tentang Pencegahan Kejahatan dan Pembinaan Pelanggar Hukum (The Prevention of Crime and Treatment of Offender) tahun 1975 kemudian dipertegas kembali dalam Kongres PBB VII tahun 1985, menunjukan bahwa terdapat kejahatan bentuk baru, yaitu kejahatan yang dilakukan oleh korporasi yang digerakkan oleh Penguasa terhormat yang membawa dampak yang sangat negatif pada perekonomian Negara yang bersangkutan. $^{4}$

Korporasi sangat memegang penting peranan arus pertumbuhan ekonomi suatu negara baik itu korporasi nasional atau multinasional, terutama peranan koperasi dalam perubahan serta pertumbu-han ekonomi suatu negara, hal tersebut membuat korporasi memiliki andil besar dalam perekonomian sehingga dapat pula membuat negara mengalami kerugian, kerugian tersebut tentunya adalah berkaitan dengan kejahatan Tindak Pidana Korupsi seperti suap pada birokrasi sehingga memenangkan proyek Pengadaan barang/jasa dan kejahatan-kejahatan lainnya yang tentunya berbasis pada Tindak Pidana Korupsi, kejahatan korporasi dapat juga berhubungan dengan Kejahatan Ekonomi yang berbasis teknologi tinggi, seperti cyber crime, pemalsuan uang, pemalsuan kartu kredit, penyelundupan, money laun-

${ }^{3}$ Soedjono Dirdjosisworo, Hukum Pidana Indonesia dan Gelagat Kriminalitas Masyarakat Pascaindustri, Pidato Pengukuhan Jabatan Guru Besar pada FH UNPAR, Bandung, 1991, hlm. 10.

4 Andi Hamzah, Kejahatan dibidang Ekonomi dan Cara Penanggulangannya, Makalah, Jakarta, 1994, hlm. 1. dering serta kejahatan canggih lainnya, pelbagai kejahatan canggih tersebut tidak mungkin terjadi tanpa bantuan dari mereka yang memiliki profesionalisme tinggi. ${ }^{5}$ Pada titik ini terjadilah yang disebut dengan kapitalisasi global. Suatu kondisi dimana ekonomi dunia hanya dikuasai oleh negara tertentu dengan mengandalkan korporasi nasional atau multinasionalnya. ${ }^{6}$

Kehadiran korporasi ibarat dua sisi mata pisau, disatu sisi korporasi dapat membuat perubahan dan perkembangan perekonomian sebuah negara, disisi lain dapat pula membuat sebuah negara menurun perkembangan perekonomiannya, atau berdampak lebih parah yaitu menjadi dalang terjadinya kejahatan. Kejahatan yang berkenaan dengan korporasi adalah pencemaran lingkungan, pengrusakan hutan, penghancuran populasi perikanan dan perilaku suap atau korupsi serta pencucian uang. ${ }^{7}$ Hal tersebut bukan hanya berdampak pada keadaan ekonomi sebuah Negara tetapi dapat juga mempengaruhi terjadinya penguasaan sektoral pada subsistem oleh pihak-pihak tertentu yang memiliki kuasa atau kemampuan ekonomi lebih, sehingga menciptakan keadaan masyarakat yang terpecah yang mempunyai kepentingan hidup yang bertentangan satu sama lain, umpamanya golongan bangsawan lawan golongan rakyat jelata, golongan kapitalis lawan golongan buruh dan tani. ${ }^{8}$ Sehingga membuat tujuan Negara dan kerja-kerjanya tak dapat Dilaksanakan dan berujung pada kehancuran perekonomian dan merebaknya kejahatan

kriminal.

5 Muladi dan Dwidja Priyatno, Pertanggungjawaban Pidana Korporasi, Jakarta, Kencana Prenada Media Group, 2012, hlm 2.

${ }^{6}$ David J. Bederman, 2008, Globalization and internasional Law, New York, Palgrave Macmilan, hlm. 104-105

Muladi dan Dwidja Priyatno, Pertanggungjawaban Pidana Korporasi, (Edisi Revisi), Kencana Prenada Media Group, Jakarta, 2013, hlm 2.

8 Usep Ranawijaya, Hukum Tata Negara Indonesia : dasar dasarnya, Jakarta, Galia Indonesia, 1983, hlm. 99. 
Dengan begitu pada perkembangannya globalisasi adalah sesuatu yang tidak dapat ditolak, sehingga membuat negara haruslah memiliki keharusan untuk mewaspadainya dengan menfungsikan hukum berjalan setara dengan perkembangan zaman, hal tersebut yang harus menjadi catatan penting ialah aturan-aturan hukum mengenai korporasi yang memiliki andil besar dalam perkembangan perekonomian negara, karena kehadirannya dapat memicu kejahatan korporasi yang berdampak besar pada kejahatan-kejahatan berteknologi tinggi serta kejahatan dengan transaksi internasional. Menurut I.S. Susanto, kejahatan korporasi adalah tindakan-tindakan yang dapat dikenai sanksi, baik sanksi pidana, perdata maupun administrasi, yang berupa tindakan penyalahgunaan secara melawan hukum kekuasaan ekonomi (illegal abuses of power) seperti produkproduk industri yang membahayakan kesehatan dan jiwa, penipuan terhadap konsumen, pelanggaran terhadap peraturan perburuhan, iklan-iklan yang menyesatkan, pencemaran lingkungan, manipulasi pajak dan korupsi. ${ }^{9}$

Hal tersebut juga berakibat pada Kejahatan korporasi yang semakin canggih, baik bentuk atau jenisnya maupun modus operandinya sering melampaui batas-batas Negara (transborderscrime) dan juga sering dipengaruhi oleh Negara lain akibat era globalisasi. ${ }^{10}$ Disamping itu sebagai dampak era globalisasi, kejahatan korporasi yang menonjol adalah price fixing (mempermainkan harga barang secara tidak sah), false advertising (penipuan iklan) seperti dibidang farmasi (obat-obatan), dan kejahatan lingkungan hidup (environmental crime), ${ }^{11}$ serta kejahatan

9 I.S. Susanto, Kriminologi, Semarang, Fakultas Hukum Universitas Diponegoro, 1995, hlm. 83

4.

${ }^{10}$ Muladi dan Dwija Priyatno, Op.Cit, hlm

11 Dwija Priyatno, “Antisipasi Hukum Pidana Terhadap Kejahatan Korporasi dalam Era Globalisasi”, dalam Karya Vira jati No. 90, Tahun 1995, Seskoad, Bandung, 1995, hlm 47-48. perbankan : cyber crime, money laundering dan illegal logging.

Dalam Kitab Undang-Undang $\mathrm{Hu}-$ kum Pidana (selanjutnya disebut KUHP) tidak mengenal pertanggungjawaban $\mathrm{Pi}$ dana Korporasi, hal demikian dikarenakan produk KUHP yang saat ini berlaku di indonesia adalah produk yang berasal dari zaman kolonial, dan hanya mengakui serta mengenal subjek dalam tindak pidana secara umum yaitu orang (natuurlijke persoon). Diterimanya korporasi dalam pengertian badan hukum atau konsep pelaku fungsional (functional daderschap) dalam hukum pidana merupakan perkembangan yang sangat maju.Yaitu dengan menggeser doktrin yang mewarnai Wetboek van Strafrecht (KUHP). Hal mana di negeri Belanda pada saat dirumuskan para Penyusun KUHP (1886). ${ }^{12}$ Sudah memberlakukan doktrin yang dikenal dengan "universitas delinguere non potest" atau "societas delinguere non potest" yaitu badan hukum tidak dapat melakukan Tindak Pidana. atas dasar kenyataan tersebut terjadi perkembangan kejahatan selanjutnya yang semakin berkembang dan dilakukan oleh Korporasi, dan memaksa korporasi haruslah memiliki pertanggungjawaban hukum juga demi menunjang sifat hukum yang dinamis, maka pada tahun 1951 yaitu dalam Undang-Undang Penimbunan B-arang-barang dan mulai dikenal secara luas dalam Undang-Undang No. 7 Drt Tahun 1955 Tentang Tindak Pidana Ekonomi. ${ }^{13}$ Dan selanjutnya terdapat dalam Undang-Undang No. 20 Tahun 2001 tentang Perubahan atas Undang-Undang No. 31 Tahun 1999 tentang Pemberantasan Tindak Pidana Korupsi dan juga UndangUndang No. 8 Tahun 2010 tentang Pence-

12 Muladi, Demokratisasi, Hak Asasi manusia, dan Reformasi Hukum Di Indonesia, Jakarta, The Habibie Center, 2002, hlm. 157

13 Andi Hamzah, Tanggung Jawab Korporasi dalam Tindak Pidana Lingkungan Hidup, makalah yang disampaikan dalam Diskusi Dua Hari Masalah-masalah Prosedur dalam Penyelesaian Lingkungan Hidup, Jakarta, Kantor Menteri Negara KLH, 1989, hlm. 32. 
gahan dan Pemberantasan Tindak Pidana Pencucian Uang.

Hal tersebut merupakan realita bahwa dewasa ini korporasi semakin memegang peranan penting dalam kehidupan masyarakat, khususnya dalam bidang perekonomian. Keraguan pada masa lalu untuk menempatkan korporasi sebagai subjek hukum pidana yang dapat melakukan tindak pidana dan sekaligus dapat dipertanggungjawabkan dalam hukum pidana sudah bergeser. Pembuat delik memasukkan korporasi ke dalam konsep pelaku fungsional, oleh karena itu korporasi dalam dunia modern mempunyai peranan penting dalam kehidupan ekonomi yang mempunyai banyak fungsi yaitu sebagai pemberi kerja, produsen, penentu harga, pemakai devisa dan lain-lain. ${ }^{14}$

Dengan demikian, korporasi sebagai badan hukum juga merupakan hal yang dapat dimintai pertanggungjawabannya secara pidana atas tindak kejahatan yang dilakukan terkait dengan tidakan kejahatan perekonomian yang menjadi momok kejahatan terberat, karena erat kaitannya dengan kerugian Negara atau dapat membuat Negara runtuh perekonomiannya. Maka dalam rangka perkembangan-perkembangan ekonomi serta pembangunan-pembangunan insfrastruktus sebuah Negara dan untuk menjaga perekonomian dan keuangan $\mathrm{Ne}$ gara maka Negara haruslah diselamatkan dari Tindak Pidana Korupsi yang dilakukan oleh Korporasi.

Kejahatan korupsi sejak dahulu sangat merajalela, apalagi dengan bergulirnya reformasi maka semangat untuk memberantas tindak pidana korupsi yang sudah sejak lama ada, semakin berkobarkobarlagi oleh karena terbukti bahwa upaya pemberantasan tindak pidana korupsi yang telah dilakukan ternyata tidak mampu untuk mengikis habis penyakit tersebut.

Hal seperti demikian dapat dipahami sebab dalam upaya penanggulangan

14 A.Z. Abidin, Bunga Rampai Hukum Pidana, Jakarta, Pradnya Paramita, 1983, hlm.71. tindak pidana (kebijakan kriminal) pada umumnya, khususnya tindak pidana korupsi, dapat ditempuh dengan menggunakan sarana penal dan sarana non penal secara terpadu, oleh karena sarana penal saja mempunyai keterbatasan kemampu-an menaggulangi kejahatan karena sebabsebab tertentu, yang diidentifikasikan oleh Barda Nawawi Arief sebagai berikut $:{ }^{15}$

1. Sebab-sebab kejahatan yang demikian kompleks berada di luar jangkauan hukum pidana ;

2. Hukum pidana hanya merupakan bagian kecil (subsistem) dari sarana control social yang tidak mungkin mengatasi masalah kejahatan sebagai masalah kemanusiaan dan kemasyarakatan yang sangat kompleks (sebagai masalah sosiopsikologi, sosio politik, sosioekonomi, sosiokultural dan sebagainya);

3. Penggunaan hukumpidana dalam menanggulangi kejahatan hanya merupakan "kurieren an symptom" oleh karena itu hukum pidana hanya merupakan "pengobatan simptomatik" dan bukan "pengobatan kausatif";

4. Sanksi hukum pidana merupakan "remedium", yang mengandung sifat kontradiktif/paradoksal dan mengandung unsur-unsur serta efek samping yang negatif;

5. Sistem pemidanaan bersifat fragmentair dan individual/ personal, tidak bersifat struktural/fungsional;

6. Keterbatasan jenis sanksi pidana dan sistem perumusan sanksi pidana yang bersifat kaku imperatif;

7. Bekerjanya/berfungsinya hukum pidana memerlukan sarana pendukung yang lebih bervariasi dan lebih menuntut "biaya tinggi".

Upaya Penal yang telah dilakukan yaitu dengan telah dibentuknya regulasi dan peraturan Perundang-undangan terkait Pemberantasan Tindak Pidana Korupsi, sedang-

15 Barda Nawawi Arief, Beberapa Aspek Penegakan dan Pengembangan Hukum Pidana, Bandung, PT Citra Aditya Bakti, 1998, hlm 46-47. 
kan Upaya Non Penal yang telah dilakukan ialah dengan melakukan dan membuat para Pelaku tindak pidana korupsi malu dengan cara peliputan di berbagai media serta operasi tangkap tangan (OTT) terhadap koruptor yang dilakukan oleh Komisi Pemberantasan Korupsi (KPK).

Semangat pemberantasan tindak pidana korupsi setelah reformasi digulirkan ditandai dengan dibuatnya berbagai produk perundang-undangan sebagai berikut $:^{16}$

1. TAP MPR Nomor XI/MPR/1998 tentang "Penyelenggaraan Negara Yang Bersih dan Bebas Korupsi, Kolusi, dan Nepotisme (KKN)";

2. Undang-Undang Nomor 28 Tahun 1999 tentang "Penyelenggaraan Negara YangBersihdan Bebas Dari Korupsi, Kolusi dan Nepotisme (KKN)"yangdidalamnya memuat ketentuan kriminalistik delik "kolusi" (pasal 21)dan delik "nepotisme" (pasal 22); dan

3. Undang-Undang Nomor 31 Tahun 1999 tentang "Pemberantasan Tindak Pidana Korupsi”, yang mengubah dan menggantikan undang-undang lama (UU No. 3 Tahun 1971). Kebijakan legislative itu masih ditambah lagi dengan keluarnya beberapa Peraturan Pemerintah dan Keputusan Presiden yang berhubungan dengan "Tata Cara Pemeriksaan Kekayaan Penyelenggara Negara", "Komisi Pemeriksaan Kekayaan Penyelenggara Negara", dan "Komisi Ombudsman Nasional", Juga UU Nomor 15 tahun 2002 tentang Tindak Pidana Pencucian uang, UU Nomor 20 Tahun 2001 tentang Perubahan atas UUNo.31Tahun1999 tentang Pemberantasan Tindak Pidana Korupsi, UU No. 8 Tahun 2010 Tentang Pencegahan dan Pemberantasan Tindak Pidana Pencucian Uang, UU No. 30

16 Barda Nawawi Arief, Kapita Selekta Hukum Pidana, Bandung, PT Citra Aditya Bakti, 2003, hlm. 65-66
Tahun 2002 tentang Komisi Pemberantasan Tindak Pidana Korupsi.

Dari beberapa produk perundangundangan tersebut di atas, khususnya dalam UU No. 20 Tahun 2001 juncto UU No. 31 Tahun 1999 diatur tentang kor-porasi sebagai subjek hukumpidana. Hal ini sesuai dengan perkembangan akhir-akhir ini, dimana kejahatankorporasi merupakan suatu gejala baru abad ke 20. Apalagi ditambah dengan berkembangnya kejahatan korupsi di Negara ini, tentunya memberikan kesempatan bagi pembuat regulasi yakni legislative maupun lembaga yudikatif untuk membendung tindak pidana korupsi yang dilakukan oleh Korporasi sehingga tindak pidana korupsi yang mengakar dapat ditumpas, maka dari hal itu pertanggungjawaban pidana korporasi adalah sebuah keharusan bagi negara hukum.

Undang-Undang Nomor 20 Tahun 2001 tentang Perubahan atas UndangUndang Nomor 31 tahun 1999 tentang Pemberantasan Tindak Pidana Korupsi (selanjutnya disebut UU Tipikor) telah mengatur pertanggungjawaban Korporasi atau tindakan korporasi yang dapat dihukum dalam kaitannya melakukan Kejahatan Korupsi, UU Tipikor secara jelas menyebutkan korporasi adalah kumpulan orang dan atau kekayaan yang terorganisir, baik itu merupakan badan hukum maupun bukan badan hukum. ${ }^{17}$ Pasal 20 UU Tipikor pada intinya menyebutkan jika korupsi dilakukan oleh atau atas nama korporasi, tuntutan atau penjatuhan pidana dapat dilakukan terhadap korporasi dan atau pengurusnya. Pidana pokok yang dapat dijatuhkan terhadap korporasi hanya pidana denda dengan ketentuan maksimum pidana ditambah satu pertiga.

Berkaitan dengan tujuan pemidanaan yaitu agar korporasi diberikan efek jera dalam kejahatan yang dilakukannya sudah seharusnya hukuman bagi korporasi dapat diberlakukan secara komulatif bukan

17 Emerson Yuntho, Menjerat Korupsi Korporasi, Jakarta,Harian Kompas, Edisi 3 Maret, 2017, hlm. 7. 
hanya pada UU Tipikor melainkan juga dengan UU Pencucian Uang, selain pidana denda korporasi juga dapat dijatuhkan pidana tambahan berupa pembekuan sebagian atau seluruh kegiatan usaha korporasi, pencabutan izin usaha, pembubaran dan/atau pelarangan korporasi, perampasan asset korporasi untuk Negara dan/atau pengambilalihan korporasi oleh Negara. ${ }^{18}$

Berkenaan dengan hal tersebut, Mahkamah Agung telah menerbitkan Peraturan Mahkamah Agung (PERMA) Nomor 13 Tahun 2016 tentang Tata Cara Penanganan Tindak Pidana oleh Korporasi. PERMA ini dikeluarkan untuk menjawab polemik dan perdebatan hukum yang terjadi di kalangan para akademisi dan penegak hukum mengenai persoalan pemidanaan terhadap korporasi dan sebagai hukum acara khusus yang berlaku bagi Penanganan Tindak Pidana oleh Korporasi.

Pada sistem pembuktian, PERMA ini tetap merujuk kepada sistem pembuktian yang ada dalam KUHAP (Kitab Undang-undang Hukum Acara Pidana) dan bentuk hukum acara khusus yang diatur dalam undang-undang lainnya. Dalam PERMA ini juga memberikan pedoman kepada hakim dalam memutus, dimana hakim berdasarkan bukti-bukti yang ada dapat menjatuhkan kepada salah satu saja terhadap pengurus atau korporasi dan pengurus korporasi, namun hakim juga dapat menjatuhkan hukuman kepada keduanya secara langsung, yaitu kepada Pengurus dan korporasinya. ${ }^{19}$

Dengan begitu, Korporasi sebagai salah satu pemegang landasan perkembangan perekonomian suatu Negara tin-dak dapat bertindak sewenang-wenang dalam menjalankan aktivitas ekonominya sehingga terwujud Negara Hukum yang stabil,

\footnotetext{
${ }^{18}$ Ibid., hlm 7

19 Muhammad Indra Kusumayudha, "Penanganan Tindak Pidana oleh Korporasi: analisis terhadap Peraturan Mahkamah Agung (PERMA) Nomor 13 tahun 2016",www.hukumpedia.com, diakses pada 28 Maret 2018
}

stabil dalam perkembangan hukum serta perekonomian suatu Negara, karena Korporasi sebagai Badan Hukum juga merupakan subjek hukum yang dapat bertanggungjawab terhaap perbuatan pidana yang dilakukannya dank arena saat ini begitu banyak kasus-kasus korupsi yang menimpa bang ini serta berpotensi merugikan Negara Indonesia maka sangat urgen jika hal tersebut dikaji secara mendalam.

Seperti yang dijelaskan oleh Emerson Yuntho (Anggota Badan Pekerja Indonesian Corruption Watch) bahwa, di Indonesia, keterlibatan korporasi dalam praktik korupsi dapat dicermati dari beberapa kasus yang pernah ditangani KPK. Data KPK tahun 2016 menyebutkan, lembaga ini telah menangani 146 kasus dengan tersangka pengurus korporasi atau perusahaan. Semua pengurus korporasi berhasil dijerat dan dijebloskan ke penjara, tetapi korporasinya tidak tersentuh dan tetap dapat beroperasi hingga saat ini. Dan pada tahun 2017, peluang menjerat korporasi yang terlibat korupsi semakin terbuka dengan lahirnya Peraturan Mahkamah Agung (Perma) Nomor 13 Tahun 2016 tentang Tata Cara Penanganan Tindak Pidana oleh Kor-porasi. Peraturan ini menetapkan syarat sebuah korporasi dapat dijerat dengan tindak pidana, yaitu korporasi mendapatkan keuntungan dari sebuah tindak pidana, membiarkan terjadinya tindak pidana, dan tidak mencegah terjadinya tindak pidana. ${ }^{20}$

\section{B. Perumusan Masalah}

Berdasarkan uraian latar belakang masalah diatas, maka berkesesuaian dengan topik pembahasan tersebut dapat dikemukakan rumusan masalah adalah bagaimana pertanggungjawaban pidana terhadap korporasi berdasarkan Undang-Undang Nomor 20 Tahun 2001 tentang Pemberantasan Tindak Pidana Korupsi?

\section{PEMBAHASAN}

Salah contoh kasus tindak pidana korupsi yang melibatkan korporasi adalah kasus perizinan proyek pembangunan

\footnotetext{
${ }^{20}$ Emerson Yuntho, Op.Cit., hlm 7
} 
Meikarta yang dimiliki oleh Lippo Group di Kabupaten Bekasi, Jawa Barat. Kasus Meikarta memang baru-baru ini sedang ramai diperbincangkan di media. Kasus ini menyeret pihak swasta dan Kepala Daerah beserta Pejabat Daerah Kabupaten Bekasi, yang masuk dalam pusaran tindak pidana korupsi terkait suap perizinan. Dalam kasus ini Billy Sindoro mewakili Lippo Group, selaku Direktur Operasional telah terbukti melakukan suap atas Izin Peruntukkan Penggunaan Tanah (IPPT), Izin Prinsip Penanaman Modal Dalam Negeri, Izin Lingkungan, dan Izin Mendirikan Bangunan (IMB), kepada Kepala Daerah Kabupaten Bekasi beserta pejabat di lingkup daerah Kabupaten Bekasi dimana yang bersangkutan dijatuhi pidana selama 3,5 tahun berdasarkan hasil Putusan Pengadilan Tinggi Nomor: 8/TIPIKOR/2019/PT.BDG tang-gal 9 Mei 2019. Isi putusan dimaksud adalah bahwa Billy Sindoro telah terbukti melakukan perbuatan pidana atas dakwaan pasal 5 ayat (1) huruf a dan huruf $b$ jo Pasal 5 ayat (1) huruf $b$ Undang-undang Nomor 31 Tahun 1999 sebagaimana telah diubah dengan Undang-undang Nomor 20 Tahun 2001 tentang Tindak Pidana Korupsi jo Pasal 55 ayat (1) jo Pasal 64 ayat (1) KUHP. Lippo Group disini adalah induk perusahaan dari PT Lippo Cikarang Tbk sebagai perusahaan pengembang proyek pemba-ngunan Meikarta dan PT Mahkota Sentosa, sebagai perusahaan yang mengurusi perizinannya.

Sektor swasta memainkan peranan penting dalam memelihara integritas nasional suatu negara. Korporasi dibentuk untuk mengejar laba. Jika korporasi gagal meraih laba, karyawan dan pihak-pihak terkait akan menderita, dan perlahan bangkrut. Pendapat lama yang mengatakan bahwa korporasi didirikan semata-mata untuk mengejar laba, sudah mulai memudar dan digantikan kesadaran baru, yakni korporasi punya tanggung jawab yang lebih luas, tidak saja pada pelanggan dan klien, tetapi juga pada lingkungan dan masyarakat. Termasuk di sini kesadaran bahwa "karya- wan lebih suka bekerja untuk perusahaan yang mereka nilai taat pada etika, dan itu dilakukannya dalam persaingan pasar yang berkembang pesat."

Dengan meningkatnya peranan korporasi dalam penyediaan barang dan jasa bagi masyarakat dan pelayanan publik, maka tanggung jawab korporasi yang lebih luas merupakan alat yang ampuh untuk memberantas korupsi. Dalam proses ini, korporasi melihat dirinya lebih daripada di masa yang sudah-sudah, yaitu menjadi bagian dari masyarakat sipil. Ketika mengejar laba, korporasi semata-mata memikirkan kepentingannya sendiri, tetapi ketika ikut mewujudkan tujuan dan visi masyarakat dan lingkungan yang lebih luas, perusahaan berperilaku sebagai anggota masyarakat sipil. Korporasi makin banyak yang berpandangan luas dan di berbagai negara di seluruh dunia makin banyak ditemukan standar etika kepemimpinan yang sangat tinggi di setiap tingkat manajemen. Kalau diingin-kan bahwa pasar dapat melayani kebutuhan semua pihak, maka pasar harus efektif, efisien, adil dan di atas semua itu, pasar tidak boleh korup. Karena jika korup, dampak negatifnya akan merugikan semua pihak tanpa kecuali.

Faktanya, korupsi telah mewabah dan ada dimana-mana. Korupsi bukan hanya soal pejabat pemerintahan yang menyalahgunakan jabatannya, menyelewengkan uang negara. Korupsi juga soal orang, setiap orang, kelompok sosial, dan korporasi yang menyalahgunakan kedudukannya demi mengejar tujuan dengan suap. Korporasi yang menyogok para pejabat negara demi memenangkan tender konstruksi. Korporasi yang menyuap para kepala daerah demi mendapatkan izin pertambangan, perkebunan atau izin pinjam pakai untuk real estate di dalam kawasan hutan. Kepala daerah yang berjuang dengan suap guna memperoleh kemenangan dalam Pilkada dengan mempengaruhi putusan Mahkamah Konstitusi. Beberapa orang yang berambisi menduduki puncak partai politik dengan menghimpun modal me- 
ngatur alokasi APBN dan proyek-proyek. Dan lain sebagainya.

Pada lingkup korporasi, penyua-pan dalam sektor swasta pun merajalela di seluruh dunia dan di berbagai bidang industri dan bisnis. Dalam ekonomi global sekarang ini, korupsi dalam sektor swasta sama besarnya dengan korupsi dalam sektor pemerintahan. Rekening bank asing digunakan untuk menyimpan uang suap. Menutupnutupi penyuapan dalam korporasi dapat melahirkan catatan keuangan palsu, rekening bank sebagian dirahasiakan, perhitungan pendapatan kena pajak palsu, dan staf terjangkit mental turut ambil jatah suap. Korupsi tidak dapat dibenarkan karena korupsi menghancurkan persiangan yang bebas dan adil. Juga, korupsi di pasar menghambat perkembangan sektor swasta. Pelaku-pelaku bisnis baru tidak dapat masuk, inefisiensi malah didorong bukannya dilenyapkan. Investor diliputi kekhawatiran jika modalnya dipergunakan untuk keperluan suap dan gratifikasi sehingga profit yang diharapkan sulit ditaksir.

Di beberapa negara, sistem hu-kum belum memungkinkan penuntutan sebagai badan hukum karena melanggar hukum pidana, karena masih dipegang teguh anggapan bahwa hanya manusia yang dapat mempunyai niat jahat dan melakukan kejahatan. Dan apapun yang terjadi, sanksi denda selalu dikaitkan dengan kemampuan orang seorang membayar bukan pada kemampuan korporasi membayar atau pada laba yang mungkin diraup setelah melakukan suap.

Berbeda dengan negara yang memiliki undang-undang yang memungkinkan korporasi dituntut di depan pengadilan karena kasus suap dan korupsi, maka sistem hukum akan mendorong korporasi memiliki prosedur intern untuk mematuhi hukum antikorupsi.

Menanggapi penelitian yang menunjukkan bahwa denda rata-rata yang dijatuhkan pada korporasi rata-rata hanya sekitar $20 \%$ dari kerugian yang diakibatkan oleh pelanggaran bersangkutan, Ko- misi itu memutuskan bahwa hukuman harus dikaitkan dengan jenis korporasi yang terlibat dalam pelanggaran. Dengan kata lain, "kepribadian korporasi yang baik" harus dinilai. Jika sebuah korporasi terbukti bersalah melakukan kejahatan suap, denda yang dijatuhkan sekitar tiga kali lipat dari jumlah kerugian yang ditimbulkan. Namun, bila korporasi dapat membuktikan bahwa program etikanya berjalan dengan baik, maka denda dapat dikurangi sampai 95 persen.

Pandangan ini berhubungan dengan beberapa kejadian nyata bahwa pengaduan oleh kelompok-kelompok korporasi berhasil mengubah praktik penyuapan di sejumlah negara. Namun, korporasi besar yang berada dalam kedudukan yang lebih baik sangat disarankan untuk memulai dan menarik diri dari pekerjaan yang sarat dengan suap dan ternodai korupsi. Saat ini, gerakan pencegahan korupsi global untuk dunia usaha mengarah pada pengembangan "standar integritas internal" bagi pengelolaan korporasi. Gerakan ini dilaksanakan oleh organisasi nirlaba bekerja sama dengan dunia usaha di berbagai negara. Dengan fokus pada integritas, dan mengkaji efektivitas sektor swasta sebagai pilar integritas. Kondisi yang ingin dicapai, korporasi sanggup untuk tidak menyuap jika ingin mendapatkan kontrak dari pemerintah/BUMN.

Menyikapi hal tersebut, ada empat unsur yang harus dipenuhi untuk menjerat korporasi dalam kasus korupsi.

1. Apakah perbuatan itu pertama kali dilakukan atau tidak.

2. Suatu korporasi bisa dijerat korupsi dilihat dari seberapa sering kebiasaan menyuap atau berbuat curang dalam perusahaan. "

3. Dari segi dampak. Ini dampak hanya untuk perusahaan atau lingkungan kecil atau untuk betul-betul besar.

4. Ada komitmen atasan, peraturan internal untuk melarang terjadinya penyuapan dan kecurangan. 
Dalam Undang-Undang Nomor 31 Tahun 1999 juncto Undang-Undang Nomor 20 Tahun 2001 tentang Pemberantasan Tindak Pidana Korupsi (UU Tipikor) telah diatur bahwa subyek hukum pelaku korupsi tidak saja orang, tetapi juga badan hukum atau korporasi. UU Tipikor secara jelas menyebutkan korporasi adalah kumpulan orang dan atau kekayaan yang terorganisasi, baik itu merupakan badan hukum maupun bukan badan hukum. "Pasal 20 UU Tipikor itu bunyinya sangat jelas ayat (2) tindak pidana korupsi dilakukan oleh korporasi apabila tindak pidana tersebut dilakukan oleh orang-orang baik berdasarkan hubungan kerja, maupun berdasarkan huhungan lain bertindak dalam korporasi baik sendiri maupun bersama-sama.

Apabila dalam suatu korporasi terjadi tindak pidana, maka tindak pidana tersebut dianggap dilakukan oleh pengurus korporasi. Sehingga yang dipandang sebagai pelaku tindak pidana adalah manusia alamiah (natuurlijke persoon). Asas ini merupakan contoh pemikiran pada abad ke19, dimana kesalahan menurut hukum pidana selalu disyaratkan sebagai kesalahan dari manusia.

Dalam hubungan tersebut, terkait pengungkapan kasus suap dalam perizi-nan proyek Meikarta mulai mengarah ke kejahatan korporasi. Berdasarkan identifikasi Komisi Pemberantasan Korupsi (KPK), praktik suap ini dilakukan untuk keuntungan korporasi, yakni PT Lippo Cikarang, dari izin proyek tersebut. Di mana dalam hal ini KPK mengendus enam proses perizinan berbau praktik suap. Perizinan tersebut di antaranya lzin Peruntukan Penggunaan Tanah (IPPT), lzin Prinsip Penanaman modal dalam negeri, Izin Lingkungan dan Izin Mendirikan Bangunan (IMB), hingga Rencana Detail Tata Ruang (RDTR) Kabupaten Bekasi.

Sebelumnya, KPK menetapkan sembilan orang tersangka dalam kasus suap perizinan proyek Meikarta. Lima orang dari jajaran Pemerintah Kabupaten Bekasi sebagai penerima suap, yakni Bupati Bekasi
Neneng Hassanah Yasin, Kepala Dinas PUPR Kabupaten Bekasi Jamaludin, Kepala Dinas Pemadam Kebakaran Pemkab Bekasi Sahat MBJ Nahor, Kepala Dinas DPMPTSP Kabupaten Bekasi Dewi Tisnawati, dan Kepala Bidang Tata Ruang Dinas PUPR Kabupaten Bekasi Neneng Rahmi. Kemudian empat orang swasta sebagai pemberi suap, yakni Direktur Operasional Lippo Group Billy Sindoro, konsultan Lippo Group Taryadi dan Fitra Djaja Purnama, serta Pegawai Lippo Group Henry Jasmen. Para tersangka dari jajaran pemkab Bekasi diduga menerima Rp 7 miliar sebagai bagian dari fee fase pertama dengan total Rp 13 miliar.

Pengungkapan kasus Meikarta bermula dari informasi masyarakat hingga penyelidikan sejak November 2017. Setahun kemudian, pada pertengahan Oktober 2018, KPK melakukan Operasi Tangkap Tangan (OTT) di Kabupaten Bekasi dan Surabaya.

Pada 14 Oktober 2018, KPK mengidentifikasi adanya penyerahan uang dari konsultan Lippo Group bernama Taryudi kepada Kepala Bidang Tata Ruang Dinas PUPR Kabupaten Bekasi Neneng Rahmi. Setelah penyerahan uang, keduanya, yang menggunakan mobil masing-masing, berpisah. Sejam kemudian, Tim KPK mengamankan Taryudi di jalan area Perumahan Cluster Bahama, Cika-rang, Jawa Barat. KPK menemukan uang senilai 90 ribu dolar Singapura dan Rp 23 juta di mobil Taryudi. Di saat yang bersamaan Tim KPK lainnya mengamankan konsultan Lippo Group bernama Fitra Djaja Purnama di kediamannya di Surabaya.

Masih di hari yang sama, KPK mengamankan Kepala Dinas Pekerjaan Umum dan Penataan Ruang Pemkab Bekasi Jamaludin di sebuah gedung pertemuan di Bekasi. Tim KPK mengamankan pegawai Lippo Group, Henry Jasmen, di kediamannya di Bekasi. Keesokan harinya, Tim KPK mengamankan enam orang di kediamanmya masing-masing di daerah Bekasi. Mereka adalah Sahat MBJ Nahor, Dewi Tisnawati, 
Asep Buchori, Daryanto, Kasimin, dan Sukmawatty. Berlanjut hari berikutnya, KPK memeriksa Bupati Bekasi Neneng Hassanah Yasin dan langsung menetapkannya sebagai tersangka. Setelah itu, KPK melakukan penggeledahan di 10 lokasi, di antaranya rumah pribadi Bupati Bekasi Neneng Hassanah Yasin, Kantor Bupati Bekasi, Kantor DPMPTSP Kabupaten Bekasi, rumah Billy Sindoro, hingga Gedung Matahari Tower di Tangerang. Sembilan orang ya-ng telah ditetapkan sebagai tersangka ini pun diproses di Pengadilan Tindak Pidana Korupsi (Tipikor) Bandung. Maret 2019, Hakim menetapkan empat orang pihak perusahaan, yakni Billy Sindoro, Hendry Jasmin P Sitohang, Taryadi dan Fitra Djaja Purnama, bersalah melakukan tindakan suap untuk memuluskan izin proyek Meikarta.

Billy didakwa 3,5 tahun penjara dan denda $\mathrm{Rp} 100$ juta, lebih rendah dari tuntutan jaksa lima tahun penjara dan denda Rp 200 juta. Hendri Jasmin divonis tiga tahun penjara dan denda Rp 50 juta. Sedangkan Fitra dan Taryudi divonis 1,5 tahun dan denda Rp 50 juta. Tak puas dengan putusan hakim, Pengacara Billy Sindoro dan Jaksa KPK pun melakukan banding. Dua bulan setelah vonis Billy, Hakim Pengadilan Tipikor Bandung menyatakan Neneng Hassanah terbukti menerima suap sebesar Rp 10,63 miliar dan 90 ribu dolar Singapura terkait perizinan proyek Meikarta. Neneng divonis enam tahun penjara dan denda Rp 250 juta. Belakangan, KPK kembali menetapkan dua tersangka, yakni Sekretaris Daerah Jawa Barat Iwa Karniwa dan Presiden Direktur PT Lippo Cikarang Tbk. Bartholomeus Toto. Wakil Ketua KPK Saut Situmorang menjelaskan Iwa diduga meminta uang Rp1 miliar kepada Neneng Rahmi Nurlaili terkait pengurusan Peraturan Daerah RDTR Kabupaten Bekasi 2017.RDTR itu menjadi bagian penting untuk mengurus pembangunan proyek Meikarta, di Kabupaten Bekasi. Awalnya, pada 2017 Neneng Rahmi menerima sejumlah uang yang kemudian diberi- kan ke beberapa pihak untuk memperlancar proses pembahasan Perda RDTR. Setelah Rancangan Perda diajukan, Neneng Rahmi diajak oleh Sekretaris Dinas PUPR bertemu pimpinan DPRD. "Pada pertemuan tersebut Sekretaris Dinas PUPR menyampaikan permintaan uang dari pimpinan DPRD terkait pengurusan tersebut,

Setelah disetujui oleh DPRD, Raperda ini dikirim ke Pemerintah Provinsi Jawa Barat, untuk dibahas. Namun, Raperda itu tidak segera dibahas oleh kelompok kerja (Pokja) Badan Koordinasi Penataan ruang Daerah (BKPRD). Neneng Rahmi mendapatkan informasi bahwa Iwa Karniwa meminta uang Rp 1 miliar untuk memperlancar pembahasan Raperda RDTR di tingkat pemprov. Permintaan ini pun diteruskan kepada salah satu karyawan Lippo Cikarang. Beberapa waktu kemudian, pihak Lippo menyerahkan uang kepada Neneng Rahmi. "Sekitar Desember 2017 dalam dua tahap, Neneng Rahmi melalui perantara menyerahkan uang pada tersangka IWK (Iwa) dengan total Rp 900 juta terkait dengan pengurusan RDTR di Provinsi Jawa Barat. Selain Iwa, KPK juga menjerat Bart-holomeus Toto sebagai tersangka perkara yang sama. Dia diduga menyetujui setidaknya lima kali pemberian uang kepada Bupati Bekasi Neneng Hasanah, dalam bentuk Dolar Amerika Serikat dan Ru-piah dengan total Rp 10,5 miliar.

Setelah serangkaian proses yang sudah dilakukan hingga ke pengadilan, KPK masih tetap melakukan pengembangan kasus tersebut. Kini, KPK mulai mengarahkan kasus ini bukan hanya pada individu yang terlibat, melainkan meluas menjadi tindak pidana korupsi yang dilakukan korporasi. Sebenarnya cukup mudah bagi KPK membuktikan kejahatan korporasi dalam kasus suap perizinan proyek Meikarta. Yang diuntungkan dalam kasus ini adalah korporasi, yakni Lippo Cikarang, bukan individu. "Apalagi sejumlah pelaku juga melakukan pengulangan perbuatan dengan mengun-tungkan korporasi yang sama 
KPK menilai pemidanaan korporasi adalah sebuah hal yang penting. Apalagi 80 persen korupsi yang terjadi di Indonesia melibatkan perusahaan atau pengusaha sebagai pelakunya. Dalam tindak pidana korupsi, ada persekongkolan antara penguasa dan pengusaha.

Banyak pihak mengharapkan ke depannya bahwa KPK berkomitmen akan lebih intensif berupaya mengungkap tindak pidana korupsi yang dilakukan korporasi. Wakil Ketua KPK Saut Situmorang mengatakan selama ini lembaganya baru menerapkan pidana korporasi setelah perkaranya masuk dalam tahap akhir penyelidikan. KPK berencana menerapkannya sejak awal penanganan perkara.

Dalam hubungannya dengan kasus tindak pidana korupsi yang dilakukan korporasi khususnya Billy Sundoro dengan induk korporasi Meikarto atau dalam jaringan Group Lippo tentu banyak hal yang harus diperhatikan. Di mana ada sejumlah hal-hal yang memberatkan terdakwa terkait vonis tersebut yakni Sindoro pernah terlibat korupsi dan tidak mengakui melakukan suap terkait izin Proyek Meikarta. Ada sejumlah hal-hal yang memberatkan terdakwa terkait vonis tersebut yakni Sindoro pernah terlibat korupsi dan tidak mengakui melakukan suap terkait izin Proyek Meikarta. Majelis hakim memberikan tenggat waktu selama tujuh hari untuk melakukan banding.

Terdakwa penyuap kasus perizinan proyek Meikarta, Billy Sindoro dituntut hukuman 5 tahun penjara.Billy diyakini telah melanggar Pasal 5 ayat (1) huruf b Undangundang nomor 31 tahun 1999 tentang pemberantasan tindak pidana korupsi sebagaimana diubah dengan Undang-undang nomor 20 tahun 2001 tentang perubahan atas UU Nomor 31 tahun 1999 tentang Tipikor Jo Pasal 55 ayat (1) ke-1 KUHP Jo Pasal 64 ayat (1) KUHP. Billy diyakini telah melanggar Pasal 5 ayat (1) huruf b Undangundang nomor 31 tahun 1999 tentang pemberantasan tindak pidana korupsi sebagaimana diubah dengan Undang-undang nomor 20 tahun 2001 tentang perubahan atas UU Nomor 31 tahun 1999 tentang Tipikor Jo Pasal 55 ayat (1) ke-1 KUHP Jo Pasal 64 ayat (1) KUHP.

Dalam tuntutannya, jaksa meyakini Billy memberikan suap ke Bupati Bekasi nonaktif Neneng Hassanah Yasin dan jajarannya di Pemkab Bekasi untuk memuluskan perizinan proyek Meikarta. Jaksa menyebut uang yang mengalir sebesar Rp16,18 miliar dan Sin\$ 270.000.Selain Billy, tiga terdakwa lain yakni bekas pegawai Lippo Group, Henry Jasmen, mantan konsultan Lippo Group yaitu Taryudi dan Fitra Djaja Purnama juga dituntut hukuman pidana dengan masa hukuman yang berbeda-beda.Untuk Henry Jasmen, JPU KPK menuntut hukuman 4 tahun dan denda Rp200 juta subsider 6 bulan kurungan. Sedangkan Fitra Djaja dan Taryudi samasama dituntut pidana penjara selama 2 tahun dan denda Rp100 juta subsider 3 bulan kurungan.

Jaksa menuntut majelis hakim yang mengadili dan memeriksa perkara tersebut menjatuhkan pidana penjara pada terdakwa karena diyakini bersama-sama Billy Sindoro melakukan suap ke Pemkab Bekasi untuk memuluskan izin proyek Meikarta.

Terkait dengan aspek pertanggungjawaban korporasi, di mana dalam hal ii Billy Sundoro adalah bagian dari pengurus korporasi atau pihak yang mengambil keputusan dalam korporasi, tentunya dalam hal ini bisa dipidana dengan mengacu pada bentuk pertanggungjawaban korporasi diantaranya adalah :

1. Pengurus korporasi sebagai pembuat dan penguruslah yang bertanggungjawab.

2. Korporasi sebagai pembuat dan pengurus yang bertanggungjawab.

3. Korporasi sebagai pembuat dan juga yang bertanggungjawab.

Dari pemaparan tersebut jelas bahwa terbitnya Peraturan Mahkamah Agung Nomor 13 Tahun 2016 tentang Tata Cara Penanganan Perkara Tindak Pidana oleh Korporasi ("Perma 13/2016") adalah deng- 
an tujuan untuk mengisi kekosongan hukum yang ada mengenai pertanggungjawaban pidana yang dilakukan oleh Korporasi. Di sisi lain, Perma 13/20-16") juga sebagai pedoman bagi aparat penegak hukum dalam penanganan perkara pidana yang dilakukan oleh Korporasi.

Sesuai Pasal 4 ayat (2) Perma 13/2016, dalam menjatuhkan pidana terhadap Korporasi dalam kasus ini, Hakim dapat menilai kesalahan Korporasi antara lain dengan parameter sebagai berikut:

1. Korporasi dapat memperoleh keuntungan atau manfaat dari tindak pidana tersebut atau tindak pidana tersebut dilakukan untuk kepentingan Korporasi;

2. Korporasi membiarkan terjadinya tindak pidana; atau

3. Korporasi tidak melakukan langkahlangkah yang diperlukan untuk melakukan pencegahan, mencegah dampak yang lebih besar dan memasti-kan kepatuhan terhadap ketentuan hukum yang berlaku guna menghin-dari terjadinya tindak pidana.

Apabilapada akhirnya yang bertanggung jawab adalah pengurus korporasi dalam arti manusia perorangan atau naturlijk person.

Badan hukum pada pokoknya adalah suatu badan atau perkumpulan yang dapat memiliki hak-hak dan melakukan perbuatan seperti seorang manusia, serta memiliki kekayaan sendiri, dapat digugat dan menggugat di depan hakim. ${ }^{21}$

Korporasi adalah subjek hukum (recht persoon) yang merupakan bentuk artificial person dari seorang manusia yang dapat memiliki hak dan kewajiban hukum. Yang membedakannya dengan manusia adalah korporasi sebagai subjek hukum tentunya tidak dapat dikenakan pemidanaan berupa pidana yang merampas kemerdekaan badan (penjara).

Mengingat hakikat Korporasi sebagai subjek hukum dalam bentuk artif-

21 Chidir Ali, Badan Hukum, Bandung: Alumni, 1987, hal. 19. icial person, maka Pasal 5 Perma 13/2016 telah mengatur bahwa dalam hal seorang atau lebih Pengurus Korporasi berhenti, atau meninggal dunia tidak mengakibatkan hilangnya suatu pertanggungjawaban Korporasi. Oleh karena itu, dalam Pasal 23 Perma 13/2016 juga diatur bahwa Hakim dapat menjatuhkan pidana terhadap Korporasi atau Pengurus, atau Korporasi dan Pengurus, baik secara alternatif maupun kumulatif.

Penerapanpertanggungjawaban

Korporasi, adapun sanksi atau hukum yang dapat dijatuhkan terhadap Korporasi menurut pedoman yang digariskan dalam Pasal 25 ayat (1) Perma 13/2016-adalah pidana pokok dan/atau pidana tambahan. Pidana pokok yang dapat dijatuhkan terhadap Korporasi adalah pidana denda. Sedangkan pidana tambahan yang dijatuhkan terhadap Korporasi sesuai yang diatur dalam peraturan perundang-undangan lain, yaitu Pasal 10 KUHP dan ketentuan jenis pidana lain yang tersebar dalam undangundang lain sebagai lex specialis dari KUHP yang merupakan legi generali.

Mengacu pada Pasal 4 Perma 13/2016 yang mendefinisikan bahwa untuk dapat dimintakan pertanggungjawaban pidana korporasi maka harus ada unsur kesalahan yang diantaranya:

1. Korporasi memperoleh keuntungan atau manfaat dari tindak pidana tersebut atau tindak pidana itu dilakukan untuk kepentingan korporasi;

2. Korporasi membiarkan terjadinya tindak pidana; atau

3. Korporasi tidak melakukan langkahlangkah yang diperlukan untuk melakukan pencegahan, mencegah dampak yang lebih besar dan memasti-kan kepatuhan terhadap ketentuan hukum yang berlaku guna menghin-dari terjadinya tindak pidana.

Berdasarkan hal tersebut, tentunya korporasi bisa dimintakan tanggungjawab mengingat ada hubungan hukum di dalamnya. Hubungan hukum yang diatur oleh norma hukum dinamakan hubungan hukum 
atau peristiwa hukum. Dengan terciptanya hubungan hukum itu maka terwujudlah ketertiban hukum. Hukum diwujudkan dengan peraturan, kalau orang bertindak selaras dengan peraturan hukum dikatakan bahwa ia bertindak menurut hukum atau bertindak secara juridis, di mana peraturan hukum mewajibkan orang supaya bertindak secara yuridis. ${ }^{22}$

Apabila mengacu pada definisi diatas tentu masih banyak perdebatan dalam hal implementasi dilapangan. Seperti contoh yaitu apabila korporasi menerima keuntungan, tetapi niat utama/niat awal melakukan tindak pidana adalah dari orang lain/pengurus? Dalam teori dasar penyertaan (deelneming) ada yang namanya Menyuruh Melakukan. Pihak yang disuruh melakukan tidak dapat dipidana sekalipun mungkin dia menerima keuntungan, hal ini dikarenakan orang yang disuruh melakukan tidak mengetahui hal tersebut adalah tindak pidana dan tidak berniat secara sengaja untuk melakukan tindak pidana. Kemudian pertanyaan selanjutnya sejauh mana definisi melakukan pembiaran dan tidak melakukan pencegahan akan terjadinya suatu tindak pidana? Lalu bagaimana jika pada prakteknya ada bentuk kesalahan lain yang tidak diatur dalam Peraturan Mahkamah Agung ter-sebut, dikarenakan sudah diatur secara limitatif.

Bukan hal yang tidak mungkin akan berujung penyalahgunaan kewenangan yang dilakukan oleh Aparat Penegak Hukum dikarenakan minimnya pemahaman secara mendalam terkait teori pertanggungjawaban pidana korporasi ini. Hal ini tentu menjadi tanggungjawab tersendiri bagi Aparat Pengawas Internal Pemerintah (APIP) untuk mencegah terjadinya penyalahgunaan kewenangan tersebut sebagaimana telah diatur dalam Pasal 20 UU Nomor 30 Tahun 2014 tentang Administrasi Pemerintahan. Sehingga menurut hemat Penulis secara langsung maupun tidak langsung penguasaan dan pe-

${ }^{22}$ Faisal Santiago, Pengantar Ilmu Bisnis, (Jakarta: Mitra Wacana Media, 2012), Kata Pengantar. mahaman tentang teori pertanggungjawaban pidana korporasi dalam Pemberantasan Tindak Pidana Korupsi juga menjadi tanggung jawab APIP. Hal ini dilakukan semata-mata untuk terus berkontribusi dalam hal pencegahan dan pemberantasan Tindak Pidana Korupsi dengan tetap menjunjung tinggi keadilan dalam setiap due process of law di Indonesia.

\section{KESIMPULAN}

Dengan lahirnya Perma 13/2016 korporasi bisa dimintai pertanggungjawaban terkait tindak pidana korupsi yang dilakukan oleh pengurus atau organ korporasi. Dengan demikian, pengurus merupakan direksi maupun komisaris yang telah tercantum dalam anggaran dasar sebuah korporasi. Untuk melihat direksi maupun komisaris tersebut dapat dimintai pertanggungjawaban pidana dalam hal tindak pidana korporasi, maka perlu melihat sejauh mana keterlibatan direksi atau komisaris dalam tindak pidana yang dilakukan oleh korporasi, dimana hal ini tercermin dalam adanya niat jahat (mens rea) dan perbuatan jahat (actus reus) yang dilakukan oleh direksi atau komisaris tersebut. 


\section{DAFTAR PUSTAKA}

A.Z. Abidin, Bunga Rampai Hukum Pidana, Jakarta, Pradnya Paramita, 1983.

Andi Hamzah, Kejahatan dibidang Ekonomi dan Cara Penanggulangannya,Makalah, Jakarta, 1994.

, Tanggung Jawab Korporasi dalam Tindak Pidana Lingkungan Hidup, makalah yang disampaikan dalam Diskusi Dua Hari Masalah-masalah Prosedur dalam Penyelesaian Lingkungan Hidup, Jakarta, Kantor Menteri Negara KLH, 1989.

Barda Nawawi Arief, Beberapa Aspek Penegakan dan Pengembangan Hukum Pidana, Bandung, PT Citra Aditya Bakti, 1998. , Kapita Selekta Hukum Pidana, Bandung, PT Citra Aditya Bakti, 2003.

Chidir Ali, Badan Hukum, Bandung: Alumni, 1987.

David J. Bederman, Globalization and internasional Law, New York, Palgrave Macmilan,2008.

Dwija Priyatno, "Antisipasi Hukum Pidana Terhadap Kejahatan Korporasi dalam Era Globalisasi”, dalam Karya Vira jati No. 90, Tahun 1995, Seskoad, Bandung, 1995.

Emerson Yuntho, Menjerat Korupsi Korporasi, Jakarta,Harian Kompas, Edisi 3 Maret, 2017.

Faisal Santiago, Pengantar Ilmu Bisnis, (Jakarta: Mitra Wacana Media, 2012).

I.S. Susanto, Kriminologi, Semarang, Fakultas Hukum Universitas Diponegoro, 1995.

Muhammad Indra Kusumayudha, "Penanganan Tindak Pidana oleh Korporasi: analisis terhadap Peraturan Mahkamah Agung (PERMA) Nomor 13 tahun 2016",www.hukumpedia.com, diakses pada 28 Maret 2018.

Muladi dan Dwidja Priyatno, Pertanggungjawaban Pidana Korporasi, (Edisi Revisi), Kencana Prenada Media Group, Jakarta, 2013.

Muladi, Demokratisasi, Hak Asasi manusia, dan Reformasi Hukum Di Indonesia, Jakarta, The Habibie Center, 2002.

Otje Salman dan Anthon F Susanto, Teori Hukum (Mengingat, Mengumpulkan dan Membuka Kembali), Bandung, Refika Aditama, 2013.

Soedjono Dirdjosisworo, Hukum Pidana Indonesia dan Gelagat Kriminalitas Masyarakat Pascaindustri, Pidato Pengukuhan Jabatan Guru Besar pada FH UNPAR, Bandung, 1991.

Usep Ranawijaya, Hukum Tata Negara Indonesia : dasar dasarnya, Jakarta, Galia Indonesia, 1983. 